Academic Platform Journal of Engineering and Science

\title{
Human Papilloma Virüs (HPV) Varlığının Cinsel Aktif Kadınlarda Moleküler Metodlarla Değerlendirilmesi
}

\author{
*11Mustafa Yöntem, ${ }^{2}$ Abdullah Gümüş, ${ }^{3}$ Remzi Abalı, ${ }^{4}$ Meltem Öznur, ${ }^{5}$ Fatih Erci, ${ }^{6}$ Behiç Selman Erdoğdu \\ ${ }^{1}$ Necmettin Erbakan Üniversitesi, Fen Fakültesi, Biyoteknoloji Bölümü, Konya, myontem@erbakan.edu.tr, \\ ${ }^{2}$ Kafkas Üniversitesi, Tıp Fakültesi, Tıbbi Mikrobiyoloji Anabilim Dalı, Kars, \\ ${ }^{3}$ Namık Kemal Üniversitesi, Tıp Fakültesi, Kadın Doğum Anabilim Dalı, Tekirdağ, (iD \\ ${ }^{4}$ Namık Kemal Üniversitesi, Tıp Fakültesi, Patoloji Anabilim Dalı, Tekirdağ, \\ ${ }^{5}$ Necmettin Erbakan Üniversitesi, Fen Fakültesi, Biyoteknoloji Bölümü, Konya, ferci@erbakan.edu.tr, \\ ${ }^{6}$ Necmettin Erbakan Üniversitesi, Fen Fakültesi, Moleküler Biyoloji ve Genetik Bölümü, Konya, serdogdu@erbakan.edu.tr,
}

Araştırma Makalesi

Geliş Tarihi: 16.01.2019

Kabul Tarihi: 09.02.2019

\section{$\ddot{O} \mathbf{z}$}

Bu çalışmada, anormal smear tanısı konan hastalarda, smear ve biyopsi materyallerinde PCR yöntemi ile HPV DNA analizi yapılarak sonuçların biyopsi tanısıyla karşılaştırılması amaçlanmıştır. Çalışma, yaşları 26 ile 74 arasında değişen 24 hasta üzerinde gerçekleştirilmiştir. Ele alınan vakalardan patolojik değerlendirme sonucunda H-SIL, L-SIL veya ASCUS ile anormal smear tanısı konmuş hastalara kolposkopik biyopsi yapılarak örnekler elde edilmiş ve moleküler testler ile HPV varlığı araştırılmıştır. Kolposkopi öncesinde hastalara anket uygulanarak demografik bilgiler elde edilmiş ve HPV enfeksiyonuna neden olabilecek faktörlerin varlığı incelenmiştir. Anormal smear sonucuna sahip hastalardan alınan patolojik örneklerde, biyopsi tanısı \%33'ünde serviks CA, \%4'ünde H-SIL, \%13'ünde L-SIL ve \%50'si normal olarak bulunmuştur. Ayrıca, normal smear sonucuna sahip tüm hastaların \%33'ünde HPV DNA belirlenmiş ve belirlenen HPV alt tipleri (HPV 16, HPV 18, HPV 31 ve HPV 58) arasında en yükssek oranda izlenen alt tipin HPV 16 olduğu tespit edilmiştir. HPV 16 bulunan 5 hastadan 4 'ünün biyopsi tanısının serviks CA olduğu tespit edilmiş, kalan 1 hastanın ise H-SIL olduğu görülmüştür. Ayrıca, partner sayısı 1'den fazla olan kişilerde HPV pozitiflik oranının yüksek olduğu görülürken, HPV pozitif vakaların tamamının gravide sayısının üç veya üzeri olduğu gözlenmiştir. Bu çalışmada patolojik tanı yöntemleri ve mikrobiyolojik inceleme sonuçlarının tanıya katkısı ortaya konulmuş, tarama programlarının ve erken teşhisin önemi bir kez daha ortaya çıkarılmıştır.

Anahtar Kelimeler: HPV, servikal intraepitelyal neoplazi, serviks kanseri, smear.

\section{Evaluation of Human Papilloma Virus (HPV) Existance with Molecular Methods in Sexually Active Women}

\author{
${ }^{* 1}$ Mustafa Yontem, ${ }^{2}$ Abdullah Gumus, ${ }^{3}$ Remzi Abalı, ${ }^{4}$ Meltem Öznur, ${ }^{5}$ Fatih Erci, ${ }^{6}$ Behiç Selman Erdoğdu \\ ${ }^{1}$ Necmettin Erbakan University, Faculty of Science, Department of Biotechnology, Konya, myontem@erbakan.edu.tr \\ ${ }^{2}$ Kafkas University, Faculty of Medicine, Department of Medical Microbiology, Kars \\ ${ }^{3}$ Namık Kemal University, Faculty of Medicine, Department of Gynecology, Tekirdag \\ ${ }^{4}$ Namık Kemal University, Faculty of Medicine, Department of Pathology, Tekirdag \\ ${ }^{5}$ Necmettin Erbakan University, Faculty of Science, Department of Biotechnology, Konya, ferci@erbakan.edu.tr \\ ${ }^{6} \mathrm{Necmettin}$ Erbakan University, Faculty of Science, Department of Molecular Biology and Genetics, Konya, \\ serdogdu@erbakan.edu.tr
}

\begin{abstract}
The aim of this study was to determine HPV DNA by PCR in smear and biopsy materials in patients with abnormal smear and to compare the results with biopsy. The study included 24 patients aged 26 to 74 years. Patients with H-SIL, L-SIL or ASCUS
\end{abstract}


who were diagnosed with abnormal smear during the pathological evaluation were evaluated and the presence of HPV was investigated with molecular tests. Demographic information was obtained from patients before colposcopy and the presence of factors that may cause HPV infection were examined. In pathological specimens taken from patients with abnormal smear results, biopsy was diagnosed as cervical CA in $33 \%$, H-SIL in $4 \%$, L-SIL in 13\%, and normal in $50 \%$ of patients. HPV DNA was determined, and it was observed that HPV 16 was the highest prevalence of HPV subtypes (HPV 16, HPV 18, HPV 31 and HPV 58). Of the 5 patients with HPV 16, 4 were found to have cervical CA, while the remaining 1 was H-SIL. In addition, the HPV positivity rate was higher in people with more than 1 partner, whereas the number of HPV positive cases was three or more in gravity. In this study; the contribution of pathological diagnostic methods and microbiological results to the diagnosis, and the importance of the scanning programs and early diagnosis was revealed.

Keywords: Cervical cancer, cervical intraepithelial neoplasia, HPV, smear.

\section{GİRIŞ}

Serviks kanseri, son derece etkili önleme ve tarama yöntemlerine rağmen dünya çapında kadınlar için önemli bir halk sağlığı sorunudur [1]. Her yıl dünyada 528.000 yeni hasta ve 266.000 ölüm vakası ile kansere bağlı ölümlerin önde gelen nedenlerinden biri olup görülme sıklığı diğer tüm jinekolojik tümörlerden daha fazladır. Olguların $\% 95$ 'i karsinojenik insan papilloma virüsünün (HPV) kalıcı enfeksiyonlarından kaynaklanır [2-4]. İnsan papilloma virüsleri Papillomaviridae familyasına ait çift zincirli DNA virüsleridir [5]. Servikal neoplaziler ve diğer anogenital ve orofaringeal kanserlerden sorumlu olan 13 yüksek riskli tip dahil olmak üzere 100 'den fazla insan papilloma virüsü türü tanımlanmıştır [6]. HPV tip 16 ve 18 tüm servikal kanserin yaklaşı1k \% 70'ini oluşturur ve bu enfeksiyona sahip olan kadınların yaklaşık \% 24'ünde tip 16; \% 9 civarında ise Tip 18 tespit edilmiştir [7].

HPV'lerin onkojenik potansiyeli, HPV yaşam döngüsünün erken aşamalarında (E6 ve E7) eksprese edilen ve sırasıyla konakçı-tümör süpresör proteinleri p53 ve pRb'ye bağlanan ve bunları inaktive eden iki onkoproteine atfedilmektedir [8]. HPV enfeksiyonu etiyolojik olarak anüs, serviks, orofarinks, penis, vajina ve vulva kanserlerinin bir alt kümesi ile ilişkilidir ve bu kanserlerdeki rolü, moleküler ve epidemiyolojik araştırmalardan elde edilen kapsamlı kanıtlarla desteklenmiştir $[9,10]$.

Prekanseröz lezyonların erken teşhisi ve tedavisi servikal kanserde ilerlemeyi engelleyebilir. $\mathrm{Bu}$ lezyonların tanımlanması esas olarak servikal hücrelerin sitolojik taraması ile gerçekleştirilmektedir. HPV DNA'sını tespit eden ve yüksek riskli HPV tiplerini düşük riskli HPV tiplerinden ayıran hassas ve spesifik moleküler teknikler sitolojiye yardımcı olarak ortaya çıkmıştır. Yüksek riskli HPV tiplerinin daha erken saptanması, enfekte hastalarda triyaj, tedavi ve takibi geliştirebilir. Günümüzde, HPV DNA testinin en belirgin rolü, sınırda veya hafif anormal sitolojik test sonuçları olan hastalarda tanısal doğruluğu arttırmak ve gereksiz kolposkopiyi sınırlamaktır [11].

HPV, serviks kanseri için gerekli bir neden olmakla birlikte, tek başına yeterli bir neden değildir. Bu nedenle, servikal HPV enfeksiyonu ile birlikte kanser oluşumu için diğer kofaktörler gereklidir. Hormonal kontraseptiflerin uzun süreli kullanımı, yüksek parite, tütün kullanımı ve HIV ile ko-enfeksiyonu belirlenen kofaktörler olarak tanımlanmıştır. Ayrıca Chlamydia trachomatis (CT) ve Herpes simplex virüs tip-2 (HSV-2) ile birlikte enfeksiyon, immünosupresyon ve bazı diyet eksiklikleri diğer olası kofaktörler olarak siralanabilir [12].

HPV enfeksiyonu, dünya genelinde en yaygın cinsel yolla bulaşan enfeksiyondur ve her iki cinsiyetten cinsel olarak aktif olan bireyler, yaşamları boyunca bir noktada bu enfeksiyona yakalanırlar [13]. Onkojenik HPV suşlarına karşı immünize olan aşıların geliştirilmesi ile servikal kanser önlenmesinde büyük adımlar atılmıştır [14]. Sitoloji tabanlı tarama yöntemlerine ek olarak (Papanicolaou veya "Pap" testi), yüksek riskli HPV enfeksiyonlarını tespit eden tarama testleri, prekanseröz lezyonların ve serviks kanserinin erken teşhis ve tedavisine yol açabilecek değerli bir araç haline gelmişlerdir. En önemli karsinojenik HPV tiplerine karşı etkili profilaktik aşılar mevcuttur. Ancak aşılanan kişilerin sayısı düşük kalmaktadır. Erken serviks kanseri cerrahi veya radyasyon ile tedavi edilebilmesine rağmen, metastatik servikal kanser tedavi edilemez ve yeni tedavi yaklaşımları gereklidir [15].

\section{MALZEME VE YÖNTEM}

\subsection{Vakaların Seçimi ve Numunelerin Alınması}

Çalışma grubu, Kadın Hastalıkları ve Doğum Polikliniğine başvuran ve rutin smear testi yaptıran hastalardan oluşturuldu. Yaşları 26 ila 74 arasında değişen (ort. 44) anormal smear tanısı konmuş 24 hasta, çalışma grubuna dahil edildi. Hastalardan Bilgilendirilmiş Gönüllü Onam Formu alınmasını takiben hastaya ait demografik bilgilerin derlenmesi ve HPV enfeksiyonu açısından risk oluşturacak faktörlerin belirlenmesi için anket yapıldı. Kolposkopi ile yapılan patolojik inceleme sonucunda H-SIL (High Grade Squamous Intraepithelial), L-SIL (Low Grade Squamous Intraepithelial) ya da ASCUS (Atypical Squamous Cells of Undetermined Significance) pozitif olan hastalardan biyopsi örnekleri alındı.

\subsection{Numunelerin İncelenmesi}

HPV'nin tip düzeyinde tanısında pek çok yöntem kullanılmaktadır. Serolojik analizler, doku kesitlerinde 
virüsün majör kapsit proteinlerini araştırma imkânı verir. Ancak çapraz reaksiyonlar nedeniyle HPV tanısında bir önemi bulunmamaktadır [16]. Bunun yanı sira blotlama metodları da tanı amaçlı kullanılabilmektedir. Polimeraz zincir reaksiyonu (PCR) ve Hybrid capture en sik tercih edilen yöntemlerdir. Hybrid capture 2 yöntemi, FDA tarafindan da onay almış ikinci kuşak bir hibridizasyon metodudur. PCR temelli yöntemler ise oldukça yüksek duyarlılıkta sonuç vermesi, 40'tan fazla HPV tipini ayırt edebilme üstünlüğüne sahip olması ve kısıtlı sayıdaki örneklerde bile tatmin edici sonuçlar vermesi açısından daha avantajlıdırv [17]. $\mathrm{Bu}$ çalışmada, HPV kültürü yapılmadığından ve serolojik yöntemlerin klinik tanıda önemi olmadığından PCR esaslı yöntem tercih edilmiştir.

Servikovajinal smear örnekleri geleneksel yöntemle hazırlanarak Bethesda sistemine göre değerlendirilmiştir. Biyopsi numuneleri fiksasyon ve tespit işlemlerinin ardından histopatolojik olarak incelenmiştir. Hastaların servikal sürüntü ve biyopsi numunelerinden EZ1 Advanced (QIAGEN) otomatize DNA izolasyon cihazı ile elde edilen viral DNA örnekleri PCR işlemine tabi tutularak virüs genomu araştırılmış ve pozitif sonuç veren örneklerden virüsün tipi belirlenmiştir. Digene HC2 HPV DNA Testi (QIAGEN) kullanılarak 13 yüksek riskli HPV tipinin (16/18/31/33/35/39/45/51/52/56/58/59/68) kalitatif saptaması 96'lık mikroplakada gerçekleştirilmiştir.

\section{BULGULAR}

Kadın Hastalıkları ve Doğum Polikliniğine başvuran hastalardan çalışma grubuna dahil edilen 24 kişiye ait demografik bilgiler Şekil 1 ve Tablo 1'de belirtilmiştir.

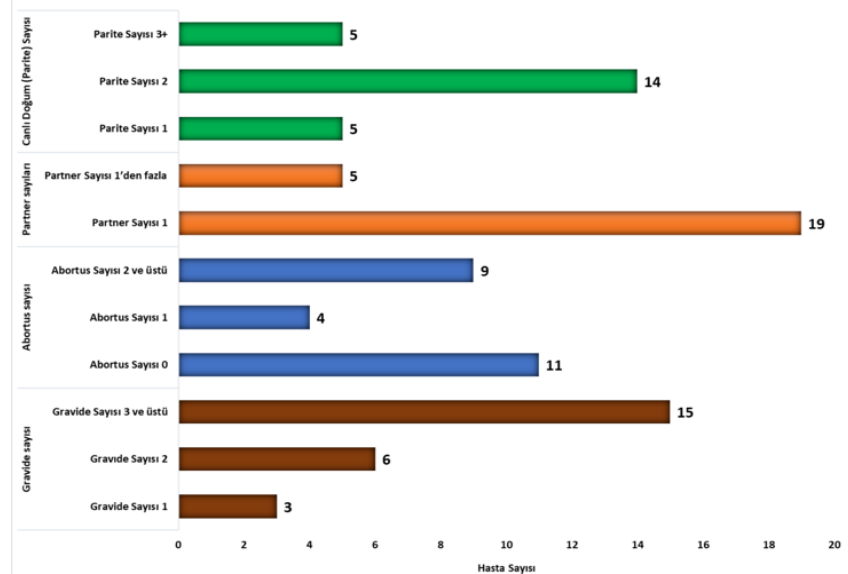

Şekil 1. Çalışmada yer alan vakaların parite, partner, abortus ve gravide sayıları

Hastaların ilk koit yaşının 16-29 (ort. 20) arasında olduğu; çalışma grubunda yer alan vakaların yarısının 20 yaş üzerinde ilk koit yaşadıkları tespit edildi. Hastaların ilk gebelik (parite) yaşının 16-28 arasında olduğu; parite sayısı 1 olan 5, 2 olan 14, 3 ve üzeri olan ise 15 hasta olduğu tespit edildi. Partner sayıs1 1 olan 19 hasta, 2 ve üzeri olan 5 hasta; hiç abortus yapmamış 11 hasta, abortus sayısı 1 olan 4 hasta,
2 ve üzeri olan ise 9 hasta olduğu bulundu. Gravide sayısı ile HPV pozitiflik oranlarına bakıldığında ise HPV pozitif olan hastaların tamamının 3 ve üzeri olduğu gözlendi.

Tablo 1. Hastaların yaş ve HPV enfeksiyonu yönünden değerlendirilmesi

\begin{tabular}{ccc} 
Yaş grupları & $\begin{array}{c}\text { Hasta sayısı } \\
(\boldsymbol{\%})\end{array}$ & $\begin{array}{c}\text { HPV (+) sayısı } \\
(\boldsymbol{\%})\end{array}$ \\
\hline $20-29$ & $3(12,50)$ & - \\
$30-39$ & $7(29,16)$ & $3(37,5)$ \\
$40-49$ & $7(29,16)$ & $1(12,5)$ \\
$50-59$ & $3(12,50)$ & $1(12,5)$ \\
$60+$ & $4(16,66)$ & $3(37,5)$ \\
\hline $\begin{array}{c}\text { Toplam Hasta } \\
\text { Sayısı }\end{array}$ & 24 & 8 \\
\hline
\end{tabular}

Sigaranın servikal kanser üzerindeki olumsuz etkisi göz önüne alındığında, çalışmamızda HPV DNA pozitif olan 8 hastanın 3'ünün sigara içtiği, 5 'inin ise içmediği tespit edildi.

Smear ve kolposkopik biyopsi örneklerinden elde edilen sonuçlar Tablo 2 ve Şekil 2'de gösterilmiştir. Elde edilen smear sonuçlarından hastaların \%50'sinin normal, \%13'ünün L-SIL, \%4'ünün H-SIL ve geriye kalan \%33'ünün de rahim ağzı kanseri olduğu sonucuna ulaşıldı.

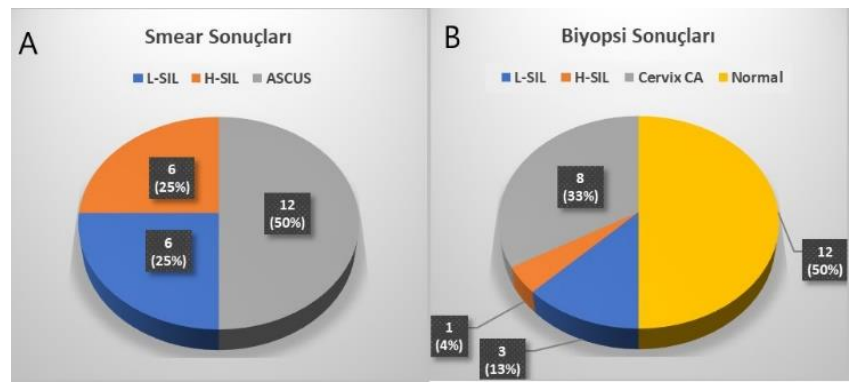

Şekil 2. Çalışmada yer alan vakaların A. Smear B. Biyopsi sonuçları

Tablo 2. Biyopsi tanısına göre HPV tiplerinin tanımı

\begin{tabular}{lcccc} 
& $\begin{array}{c}\text { Cervix } \\
\text { CA }\end{array}$ & H-SIL & L-SIL & Normal \\
\hline HPV 16 & 4 & 1 & - & - \\
HPV 18 & - & - & - & 1 \\
HPV 31 & - & 1 & - & - \\
HPV 58 & 1 & - & - & - \\
\hline
\end{tabular}

Biyopsi sonuçlarına göre; pozitif HPV olan hastalardan HPV tip 16 olan 5 hastanın 4'ünün serviks CA, 1 hastanın ise $\mathrm{H}$ SIL olduğu belirlendi. Diğer taraftan HPV tip 18 olan hastanın biyopsi sonucunun normal, HPV subtip 31 olan hastanın ise H-SIL olduğu ve HPV subtip 58 olan hastaya serviks CA tanısı konduğu tespit edildi. 


\section{DEĞERLENDIRME VE SONUÇ}

HPV, dünya çapında hem erkek hem de kadınlarda cinsel yolla bulaşan hastalıkların en yaygın nedenlerinden biridir. HPV enfeksiyonunun, zararsiz lezyonlardan kansere kadar pek çok durumla ilişkili olduğu bilinmektedir [11]. Serviks kanseri, dünya genelinde kadınlarda en sık görülen ikinci kanser türüdür. Ortaya çıkışına ve patogenezine dair bilgiler sürekli olarak artmaktadır. Yakın dönemde yapılmış çalışmalar, HPV enfeksiyonunun serviks kanserinin temel sebebi olduğunu ortaya koymaktadır. Kalıcı enfeksiyonlara yol açan yaklaşık 15 karsinojen HPV türünün ise hemen hemen bütün vakaların altında yatan neden olduğu iddia edilmektedir $[6,18]$.

HPV enfeksiyonunun neden olduğu rahim kanserinin histopatolojik ilerleyişi diğer kanser türlerine göre farklıdır. Sitolojik anormallik olsun ya da olmasın, servikal HPV enfeksiyonlarının büyük bir kısmı virüs bulaştıktan sonraki 1-2 yıl boyunca hücresel immün sistem tarafindan baskılanır. Enfeksiyon ve prekanserin ilk mikroskobik kanıtının ortaya çıkması 5 yıl gibi kısa bir sürede gerçekleşebilir [3, 19]. Prekanser dönem, genetik anormalliklere sahip ancak farklılaşmamış hücrelerin neredeyse servikal epitelyumun tam kalınlığının yerini almasıyla karakterizedir. Sigara, multiparite, beslenme, uzun süre doğum kontrol haplarının kullanımı, kanserojen HPV tipleri ile enfekte olmuş kadınlarda prekanser ve kanser riskini iki ya da üç katına kadar çıkarabilmektedir [20, 21].

Prekanserin ortalama teşhis yaşı 25 ila 35 yaşlar arasındadır. İnvaziv servikal kanserin piki diğer yetişkin kanser türlerine kıyasla daha erken görülüp 35-55 yaş arasındaki bireylerde bir plato oluşturur[3].

PCR, HPV'nin gen düzeyinde tanımlanmasında ve klinik tanıda büyük kolaylık sağlayan bir yöntemdir. Az miktarda örnekle bile yüksek doğrulukta sonuç vermesi, izole edilen virütik genomun kanserojen özellikte olup olmadığını tanımlamada çok daha avantajlı olmasından dolayı birçok araştırmacı gibi biz de bu metodu tercih ettik. Yapmış olduğumuz literatür taramasında da servikal kanserli hastalarda PCR temelli metotlarla yüksek oranda HPV pozitiflik olduğunun iddia edildiği tespit edilmiştir [20-22]. Bizim çalışmamızda servikal kanser tanısı konmuş 5 hastanın 5'inde, H-SIL tanılı 6 hastanın 2'sinde, L-SIL tanılı 6 hastanın hiçbirisinde ve ASCUS tanılı 12 hastanın 1'inde yüksek riskli HPV pozitif bulunmuştur. Ayrıca HPV 16, 18, $31,33,35,39,45,51,52,56,58,59,68,73$ ve 82 türlerinin (azalan frekansa göre) yüksek riskli (kanserojen); HPV 26, 53 ve 66 türlerinin de muhtemel kanserojen türler olarak değerlendirilmelerinin mümkün olduğu ifade edilmiştir (21). Yapmış olduğumuz literatür taramasında ırkın HPV prevalansını etkilediği, beyazlara kıyasla siyahi genç erkekler ile HPV prevalansı arasında önemli bir ilişkinin bulunduğu ifade edilirken [23], sigara kullanımının da yüksek riskli HPV pozitiflikle güçlü bir ilişkisinin olduğu ve servikal kanser riskini artırdığı iddia edilmektedir [21, 24, 25] . Bizim çalışmamızda HPV DNA pozitif olan 8 hastanın 3'ünün sigara kullanıyor olması bu bulguları desteklemektedir. Ancak başka bir çalışmada ise HPV'den bağımsız olarak, tütün içindeki kotinin ve nikotin gibi kimyasal kanserojenlerin, karsinojenik nitrozaminleri aktive ederek ve DNA hasarına neden olarak mitojenik bir etki gösterdiği ve ayrıca servikal epitelyumda lokal bağışıklık savunmasını bozabildiğinin iddia edilmektedir [20].

Sonuç olarak;

- Servikal kanser lezyonlarının ortaya çıkmasında HPV'nin önemli bir faktör olduğu,

- Sigara, beslenme, doğum kontrol hapları ve yüksek doğum sayısı, cinsel yaşam tercihi (her iki cinsiyet için çok eşlilik) ve kişisel hijyen gibi etkenlerin de servikal kanser insidansını artırdığ1,

- Servikal kanserin patogenezinde, koruyucu hekimlik ve erken tanının önemli olduğu kanaatine varıldı.

\section{REFERANSLAR}

[1].W.-J. Koh et al., "Cervical cancer, version 2.2015," Journal of the National Comprehensive Cancer Network, vol. 13, no. 4, pp. 395-404, 2015.

[2].J. Ferlay et al., "Cancer incidence and mortality worldwide: sources, methods and major patterns in GLOBOCAN 2012," International journal of cancer, vol. 136, no. 5, pp. E359-E386, 2015.

[3].M. Schiffman, N. Wentzensen, S. Wacholder, W. Kinney, J. C. Gage, and P. E. Castle, "Human papillomavirus testing in the prevention of cervical cancer," Journal of the National cancer institute, vol. 103, no. 5, pp. 368-383, 2011. [4].S. K. Kjær, K. Frederiksen, C. Munk, and T. Iftner, "Long-term absolute risk of cervical intraepithelial neoplasia grade 3 or worse following human papillomavirus infection: role of persistence," Journal of the National Cancer Institute, vol. 102, no. 19, pp. 1478-1488, 2010.

[5].E.-M. De Villiers, C. Fauquet, T. R. Broker, H.-U. Bernard, and $H$. zur Hausen, "Classification of papillomaviruses," Virology, vol. 324, no. 1, pp. 17-27, 2004.

[6].E. J. Crosbie, M. H. Einstein, S. Franceschi, and H. C. Kitchener, "Human papillomavirus and cervical cancer," The Lancet, vol. 382, no. 9895, pp. 889-899, 2013.

[7].S. De Sanjosé et al., "Worldwide prevalence and genotype distribution of cervical human papillomavirus DNA in women with normal cytology: a meta-analysis," The Lancet infectious diseases, vol. 7, no. 7, pp. 453-459, 2007. [8].K. Münger and P. M. Howley, "Human papillomavirus immortalization and transformation functions," Virus research, vol. 89, no. 2, pp. 213-228, 2002.

[9].A. K. Chaturvedi, "Beyond cervical cancer: burden of other HPV-related cancers among men and women," Journal of Adolescent Health, vol. 46, no. 4, pp. S20-S26, 2010.

[10].M. L. Gillison, A. K. Chaturvedi, and D. R. Lowy, "HPV prophylactic vaccines and the potential prevention of noncervical cancers in both men and women," Cancer, vol. 113, no. S10, pp. 3036-3046, 2008.

[11].E. M. Burd, "Human papillomavirus and cervical cancer," Clinical microbiology reviews, vol. 16, no. 1, pp. 117, 2003. 
[12].N. Munoz, X. Castellsagué, A. B. de González, and L. Gissmann, "HPV in the etiology of human cancer," Vaccine, vol. 24, pp. S1-S10, 2006.

[13].E. F. Dunne et al., "Prevalence of HPV infection among females in the United States," Jama, vol. 297, no. 8, pp. 813819, 2007.

[14].M. Arbyn and J. Dillner, "Review of current knowledge on HPV vaccination: an appendix to the European Guidelines for Quality Assurance in Cervical Cancer Screening," Journal of Clinical Virology, vol. 38, no. 3, pp. 189-197, 2007.

[15].C. G. A. R. Network, "Integrated genomic and molecular characterization of cervical cancer," Nature, vol. 543, no. 7645, p. 378, 2017.

[16].A. Ağaçfidan, "Cinsel yolla bulaG̣an hastalıklarda laboratuvarda tanı olanakları," ANKEM Dergisi, vol. 26, pp. 189-197, 2012.

[17].F. Sahiner, "Current problems and recent advances in the molecular diagnosis of genital human papillomavirus infections," Mikrobiyol Bul, vol. 48, no. 4, pp. 689-706, 2014.

[18].M. Schiffman, P. E. Castle, J. Jeronimo, A. C. Rodriguez, and S. Wacholder, "Human papillomavirus and cervical cancer," The Lancet, vol. 370, no. 9590, pp. 890907, 2007.

[19].C. B. Woodman et al., "Natural history of cervical human papillomavirus infection in young women: a longitudinal cohort study," The Lancet, vol. 357, no. 9271, pp. 1831-1836, 2001.

[20].L. Kjellberg et al., "Smoking, diet, pregnancy and oral contraceptive use as risk factors for cervical intra-epithelial neoplasia in relation to human papillomavirus infection," British journal of cancer, vol. 82, no. 7, p. 1332, 2000.

[21].H. Yetimalar, A. Köksal, M. İnceoğlu, and B. Kasap, "Premalign ve malign servikal lezyonlu hastalarda HPV enfeksiyonu," Türk Jinekoloji ve Obstetrik Derneği Dergisi, vol. 6, no. 4, p. 273, 2009.

[22].N. Muñoz et al., "Epidemiologic classification of human papillomavirus types associated with cervical cancer," New England Journal of Medicine, vol. 348, no. 6, pp. 518-527, 2003.

[23].L. E. Manhart et al., "Human papillomavirus infection among sexually active young women in the United States: implications for developing a vaccination strategy," Sexually transmitted diseases, vol. 33, no. 8, pp. 502-508, 2006.

[24].E. Mazarico, R. Gómez, L. Guirado, N. Lorente, and E. Gonzalez-Bosquet, "Relationship between smoking, HPV infection, and risk of cervical cancer," Eur. J. Gynaec. Oncol.-ISSN, vol. 392, p. 2936, 2015.

[25].R. C. Eldridge et al., "Smoking and subsequent human papillomavirus infection: A mediation analysis," Annals of epidemiology, vol. 27, no. 11, pp. 724-730. e1, 2017. 